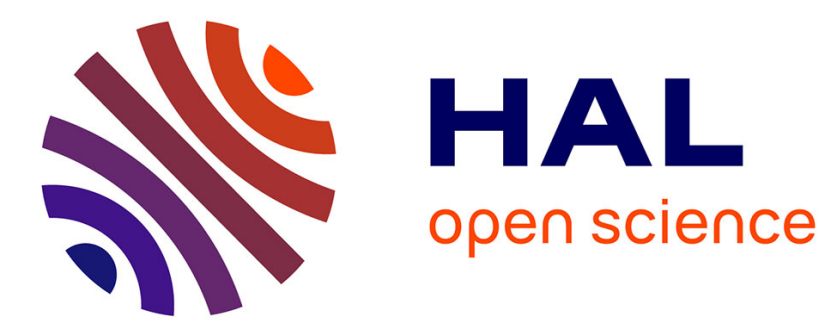

\title{
Dog molars as personal ornaments in a Kura-Araxes child burial (Kalavan-1, Armenia)
}

Modwene Poulmarc'H, Rozalia Christidou, Adrian Bălășescu, Hala Alarashi, Françoise Le Mort, Boris Gasparyan, Christine Chataigner

\section{- To cite this version:}

Modwene Poulmarc'H, Rozalia Christidou, Adrian Bălășescu, Hala Alarashi, Françoise Le Mort, et al.. Dog molars as personal ornaments in a Kura-Araxes child burial (Kalavan-1, Armenia). Antiquity, 2016, 90 (352), pp.953-972. 10.15184/aqy.2016.132 . hal-01806691

\section{HAL Id: hal-01806691 https://hal.science/hal-01806691}

Submitted on 28 Nov 2021

HAL is a multi-disciplinary open access archive for the deposit and dissemination of scientific research documents, whether they are published or not. The documents may come from teaching and research institutions in France or abroad, or from public or private research centers.
L'archive ouverte pluridisciplinaire $\mathbf{H A L}$, est destinée au dépôt et à la diffusion de documents scientifiques de niveau recherche, publiés ou non, émanant des établissements d'enseignement et de recherche français ou étrangers, des laboratoires publics ou privés. 


\section{Dog molars as personal ornaments in a Kura-Araxes child burial (Kalavan-1, Armenia)}

Modwene Poulmarc'h ${ }^{1}$, Rozalia Christidou ${ }^{1}$, Adrian Bălăşescu ${ }^{2}$, Hala Alarashi ${ }^{1}$, Françoise Le Mort ${ }^{1}$, Boris Gasparyan ${ }^{3}$ $\&$ Christine Chataigner ${ }^{1}$

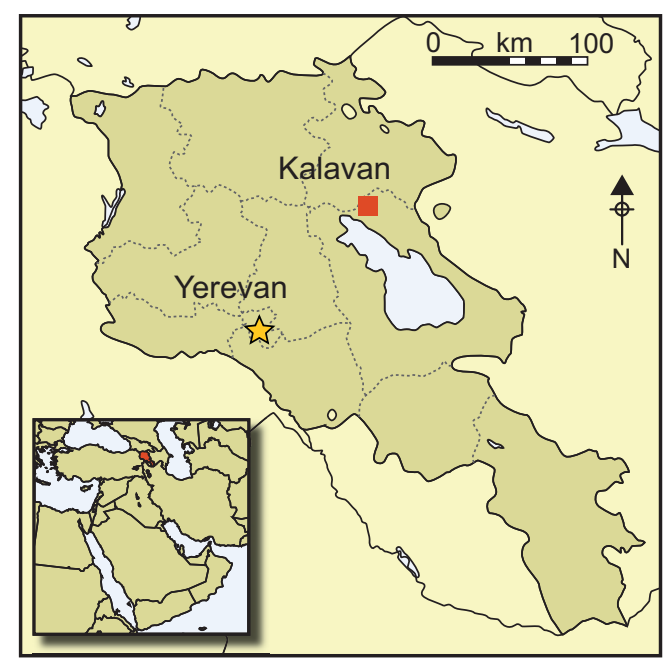

Two perforated dog molars were found directly associated with a Kura-Araxes child burial from the third millennium $B C$ in Armenia. Both teeth show trimming of the root ends and boring of a biconical hole through the lingual root with a hand-held stone tool. Expedient manufacture, the anatomical location of the hole and use-wear suggest that the molars were suspended in order to display their crowns as part of a necklace that also included two stone beads. This is an unusual type of personal ornament and the first of its kind reported in the South Caucasus. Its use in a Kura-Araxes burial is interpreted as an active modification of the funerary symbolism during this period.

Keywords: Armenia, Early Bronze Age, Kura-Araxes burial, perforated dog molar, microwear analysis

\section{Introduction}

Recent approaches to the social and cognitive dimensions of the use of animal species or their bones in burials and in artefact production consider human-animal relationships as integral to the use practices (e.g. Choyke 2010; Morey 2010; Losey et al. 2011). The practices are interpreted in terms of cultural attitudes, but burials may be windows to individual actions. Recently, two perforated upper molars of dog (Canis familiaris) were found in direct association with a child skeleton at the Kura-Araxes burial ground of Kalavan-1,

1 UMR 5133, Archéorient: Environnements et sociétés de l'Orient ancien, CNRS-Université Lumière Lyon 2, Maison de l'Orient et de la Méditerranée, 7 rue Raulin, 69365 Lyon cedex 07, France (Email: rozalia.christidou2@gmail.com)

2 National History Museum of Romania, Calea Victoriei 12, Sector 3, Bucharest 030026, Romania

3 Institute of Archaeology and Ethnography, National Academy of Sciences of the Republic of Armenia, Charents Street 15, Yerevan 0025, Republic of Armenia 


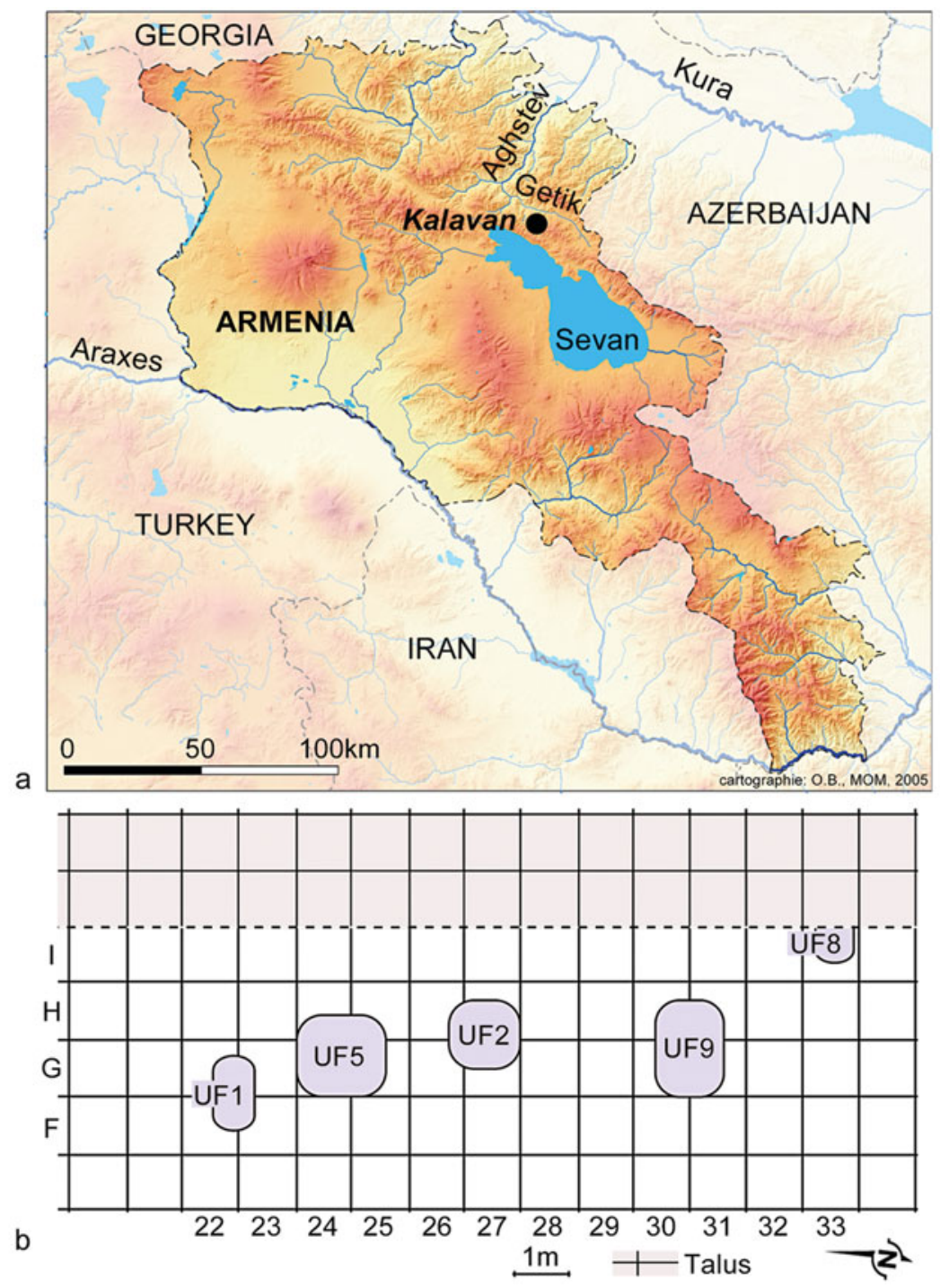

Figure 1. The location of the Kalavan-1 cemetery in Armenia (a) and the position of the burials within the excavation grid (b).

north-eastern Armenia (Figure 1). This type of tooth artefact occurs in different periods and regions, but actual finds of this kind are rare. This article examines contextual, morphological and wear data in order to explore the cultural logic that guided the use of dog molars in the ornamentation of the dead.

The Kura-Araxes cultural phenomenon, dated to 3600/3500-2500/2400 cal BC, extends throughout most of the Early Bronze Age in the South Caucasus region, and can be traced south-westwards in north-east Anatolia and, by the beginning of the third millennium, to the Upper Euphrates as far as the Mediterranean coast (e.g. Smith 2005, 2012; Kohl 2009; Chataigner \& Palumbi 2014). In the east, it stretched southwards from (C) Antiquity Publications Ltd, 2016 
south-eastern Daghestan to north-western Iran. The culture is best known for handmade burnished ceramics and numerous settlements of various types, dispersed at different environmental and altitudinal zones. The reason for this dispersal—economic buffering, population growth, cultural assimilation and so on-remains elusive, largely due to the dynamic character of the culture. Current discussions revolve around spatial, social and material variability and the multidirectional flows of people, objects and influence. With regard to mortuary activities, cemetery burials became a recurrent practice, and the process of tomb diversification that had started in the Chalcolithic period continued within the Kura-Araxes horizon (Poulmarc'h 2014; Poulmarc'h \& Le Mort 2016). Stone-built tombs appeared for the first time during this latter period and were used alongside kurgans (burial mounds) and pit graves, which could be covered with stone heaps. While the kurgans have Chalcolithic antecedents, it is not yet clear whether the stone-heap pit-graves were an entirely new phenomenon. Despite diversity, the Kura-Araxes burials are simple and contrast with their ostentatious counterparts of the north-west Caucasian Chalcolithic Maikop culture and the south Caucasian Middle Bronze Age. The Kura-Araxes grave goods, when present, are few and consist of local ceramics and personal ornaments, namely stone (usually carnelian) beads and bronze rings and bracelets. They do not relate to burial type, or to the age or gender of the deceased, suggesting that status was ascribed on an individual basis (e.g. kinship bond). This is not, however, supported by other observations in the zones of geographic expansion of the Kura-Araxes culture; for example, the association of local and non-native elements in the rich assortment of ceramic and metal artefacts from the grave of the 'Signiore di Arslantepe' in the Upper Euphrates basin (Frangipane et al. 2001).

The perforated dog molars from Kalavan-1, so far unique in the South Caucasus and adjacent regions, enrich the Kura-Araxes material assemblage. The cemetery has been assigned to this period on the basis of pottery types and absolute dates. Dog remains are rare in the faunal assemblages from the area (e.g. Mirzoyan \& Manaseryan 2008; Piro 2008; Bălășescu et al. 2010; Wilkinson et al. 2012; Berthon et al. 2013), and the molars are an even more exceptional example of body adornment. The closest comparison to the Kalavan-1 specimens is a naturally worn upper dog molar with a single perforation, discovered in a Neolithic burial at Parma-via Guidorossi, Italy, and dated to the mid fourth millennium BC (Bernabò Brea et al. 2010: 134-35 \& fig. 19). It was part of a necklace comprised exclusively of dog teeth. Geographically nearer to the Armenian specimens is an upper second dog molar with a perforated root from the Bronze Age settlement of Százhalombatta-Földvár, Hungary, dated to $c$. 2100-1600 cal BC (Choyke et al. 2004: 186 $\&$ fig. 17). Several dog and wolf molar and premolar pendants are also known from the Latvian Mesolithic and early Neolithic graves of Zvejnieki, which span c. 9000-4100 cal BC (Loungas 2006: 84-85, fig. 7; ${ }^{14} \mathrm{C}$ dates: Mannermaa et al. 2007). Also recorded is a dog's lower carnassial (first molar) with a double perforation from the late Natufian (12 000 cal BP) burial cave of Hilazon Tachtit, Israel (Grosman 2003: 575 \& fig. 6). Since the Palaeolithic, the use of canid molars and premolars in the production of portable art appears erratic, in contrast to the more frequent use of canines and incisors (e.g. Barge-Mahieu \& Taborin 1991; Vanhaeren \& d'Errico 2006). Much could be said about the selection of dogs, based on their physical state and appearance or ante mortem relation to humans (e.g. Copet-Rougier 1988). Any attempt to assess the influence of such symbolic connotations on 
Table 1. AMS radiocarbon dates from the burial ground of Kalavan-1; calibrated date ranges were obtained using IntCal13 and OxCal v4.2.

\begin{tabular}{lcccc}
\hline Laboratory code & Burial & ${ }^{14}$ C date $(\mathrm{BP})$ & cal BC $(1 \sigma)$ & cal BC $(2 \sigma)$ \\
\hline & & & & \\
UGAMS-02294 & UF5 & $4080 \pm 50$ & $2850-2498$ & $2866-2485$ \\
UGAMS-02294a & UF5 & $4160 \pm 60$ & $2876-2668$ & $2888-2580$ \\
Poz-22179 & UF5 & $4045 \pm 35$ & $2620-2491$ & $2836-2472$ \\
Poz-22180 & UF5 & $4045 \pm 35$ & $2620-2491$ & $2836-2472$ \\
Lyon-9705 (SacA-31261) & UF8 & $4020 \pm 30$ & $2572-2490$ & $2620-2471$ \\
Poz-22234 & UF9 & $3990 \pm 35$ & $2566-2472$ & $2619-2410$ \\
\hline
\end{tabular}

the mortuary behaviour in the South Caucasus region is constrained by the paucity of dog skeletal material. Below, we consider evidence for the symbolic use of canid bones during the Kura-Araxes period and discuss change in funerary artefacts. We accept that symbols can be transformed through their use (Sewell 1999: 46-47), and argue that small-scale actions, like the shaping, use and burial of dog molars, suggest such variability within the Kura-Araxes society. They may hint at individuals or groups striving to maintain social and cultural coherence in a changing economic and political environment. They may also suggest loose connections between groups and a lack of competition. As has been argued elsewhere (Hamilakis 2002: 183), "competition needs a common basis for comparison [... ] and the same media" and may concern only certain parts of the society. No such tensions or divisions are documented within the Kura-Araxes agro-pastoral communities of the South Caucasus region, which represent small-scale societies with a material culture attesting to local variability. It could be argued that the dynamism of the period provided opportunities for individual action and innovation in the symbolic sphere, while new mortuary symbols would not be tolerated or desired in a period of stability.

\section{The site and the burial ground}

Kalavan-1 is an open-air site situated $1640 \mathrm{~m}$ asl on the south-west-facing slopes of the Aregunyats Range north of Lake Sevan. Archaeological and geological investigations were conducted between 2005 and 2009 as part of a collaborative Armenian and French project (Chataigner et al. 2012; Montoya et al. 2013). The excavation revealed two main levels of occupation dated to the Terminal Palaeolithic, overlain by the Kura-Araxes burial ground. Due to the steep topography above Kalavan-1 (13-14 slope), which lies near the bottom of the deep valley of the Barepat River, a tributary of the Getik, connecting through Aghstev with the Kura River, only limited exposures of the archaeological remains were made. The total excavated area approached $70 \mathrm{~m}^{2}$. Five burial pits were uncovered, of which four, referred to as UF1, UF2, UF8 and UF9 (Figure 1b), contained single primary burials; the fifth, UF5, held the remains of at least three individuals. Six consistent ${ }^{14} \mathrm{C}$ dates on human skeletal material from UF5, UF8 and UF9 bracket the use of the burial site between $c$. 2850 and $2490 \mathrm{cal} \mathrm{BC}$ (Table 1) in the late Kura-Araxes phase. Age at death and sex were assigned to three individuals: two adult females and a juvenile aged between five years and (C) Antiquity Publications Ltd, 2016 
Table 2. Burial data from Kalavan-1.

\begin{tabular}{|c|c|c|c|}
\hline Burial & Sex of individual & Age of individual & Body orientation \\
\hline UF1 & female $^{1}$ & $20-29$ years $^{2}$ & east-west \\
\hline UF2 & undetermined & undetermined & east-west \\
\hline UF5 & 1 female & $20-29$ years $^{2}$ & unidentifiable \\
\hline UF8 & $\begin{array}{l}2 \text { undetermined } \\
\text { undetermined }\end{array}$ & $\begin{array}{l}\text { undetermined } \\
5 \text { years }+6 \text { months- } \\
\text { 6years }+6 \text { months }{ }^{3}\end{array}$ & east-west \\
\hline UF9 & undetermined & undetermined & east-west \\
\hline
\end{tabular}

Table 3. Metrical data on Kalavan-1 dog molars (measurements in millimetres). Internal diameters are approximate because of damage in the interior of the holes. The external diameter varies on each one of the cones; the values given below are indicative.

\begin{tabular}{|c|c|c|c|}
\hline & & $\mathbf{M}^{1}$ & $\mathbf{M}^{2}$ \\
\hline Length $^{a}$ & & 12.8 & 6.8 \\
\hline Breadth $^{a}$ & & 14.2 & 9.3 \\
\hline \multicolumn{4}{|c|}{ Perforation diameters } \\
\hline Internal & & $2.7 / 2$ & 1.5 \\
\hline \multirow[t]{2}{*}{ External } & mesial cone & $5.2^{\mathrm{b}} / 4.1^{\mathrm{c}}$ & $4.3^{\mathrm{b}} / 2.9^{\mathrm{c}}$ \\
\hline & distal cone & $6.4^{b} / 5.2^{c}$ & $2.8^{\mathrm{b}} / 2.6^{\mathrm{c}}$ \\
\hline \multirow[t]{3}{*}{ Root length } & mesiobuccal & 1.6 & 3.4 \\
\hline & distobuccal & 3.5 & 2.8 \\
\hline & lingual & 6.5 & 4.8 \\
\hline
\end{tabular}

${ }^{a}$ Based on von den Driesch (1976); ${ }^{b}$ length from the coronal to the apical region of the cone; ${ }^{\mathrm{c}}$ length from the mesial to the buccal region of the cone.

six months and six years and six months (Table 2). The other skeletons belonged to adults, but poor preservation precluded age or sex estimates.

The graves were excavated following the 'archaeothanatology' method, which is based on detailed analysis of the skeletal and other remains within the burial, and of the acts related to the treatment and management of the dead (Duday 2009). Stone heaps rising to around $0.7 \mathrm{~m}$ in height marked the graves of the adults. These structures were of oval plan with an average major axis of $1 \mathrm{~m}$, and of $1.7 \mathrm{~m}$ for the heap above UF5. The position of the body in the pits varied: sitting, tightly flexed and flexed. The three single adult burials yielded evidence for the post-sepulchral retrieval of bones as a mortuary practice. Movement of bones away from the initial volume of the corpse had also occurred, indicating that the body had decomposed within an 'empty space'. We propose that the deceased and associated burial goods were placed in a box made of perishable material, possibly wood. The adult burials were furnished with similar assemblages of black burnished pottery: one goblet with a tripartite profile, and two or three large bowls. UF9 also contained two bronze ornaments: a ring and a bracelet. 
The child burial, UF8 (Figure 2), represents an undisturbed deposit. The skeleton was found articulated. It was lying flexed on the right side. The east-west orientation of the

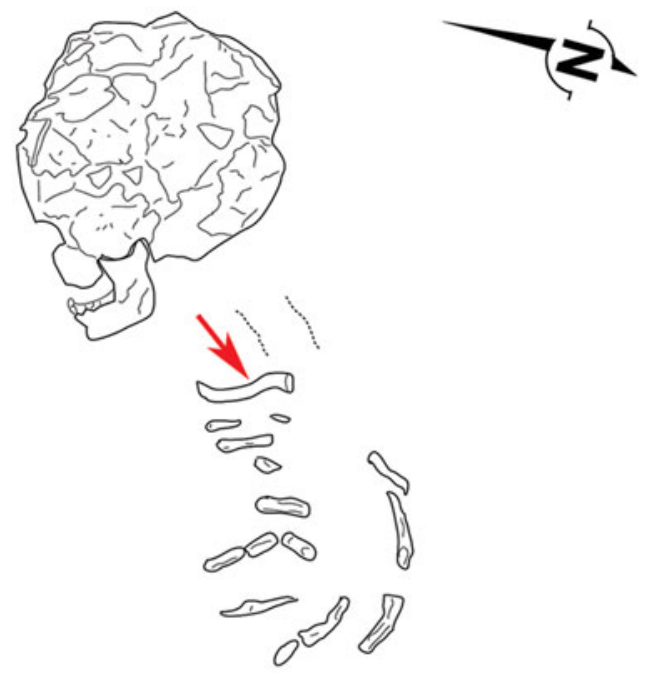
body (head to the east) conforms to the pattern observed in the single adult burials. The child was probably adorned with a neck-ornament composed of the two dog molars and two stone beads, one made from carnelian and the other from a blue stone, probably a pebble.

\section{The dog molars}

We now turn to the anatomical origin, preservation, manufacture and use of the Kalavan-1 tooth artefacts. Surface damage was studied using a stereomicroscope and a metallographic microscope of up to $200 \times$ magnification. Manufacturing and use-wear features were further examined with a scanning electron microscope. High magnifications were employed to interpret wear that had resulted in

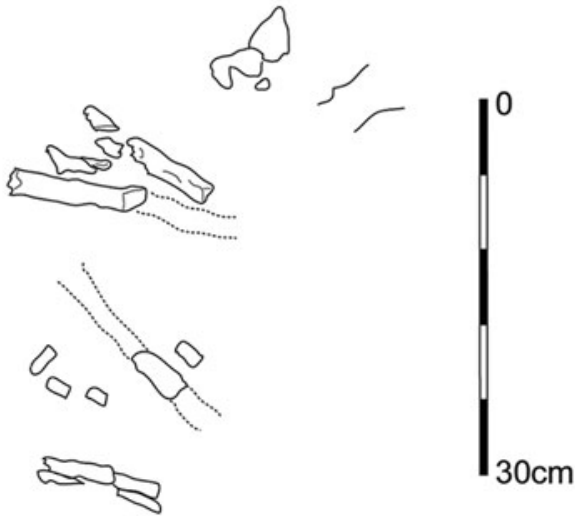

Figure 2. Plan of the child burial from Kalavan-1, Armenia (the arrow indicates the location of the ornaments; drawn by Modwene Poulmarc'h). a polished appearance (e.g. Legrand \& Sidéra 2007), and to observe the extent and variety of accidental damage.

The two specimens comprise one upper left first and one upper right second molar $\left(\mathrm{M}^{1}\right.$ and $\mathrm{M}^{2}$, respectively; Table 3 $\&$ Figures 3 \& 4a-d). In the dog, these teeth appear in the permanent dentition. Species identification was based on metrics available from prehistoric sites in Armenia and recent wolf populations of the central Balkans (Figure 4e), currently the largest and geographically closest sample to Kalavan-1. Both teeth had fully erupted, indicating animals aged six months or older (Schmid 1972: tab. X). The occluding surface of $\mathrm{M}^{1}$ displays increased wear compared to that of $\mathrm{M}^{2}$, as was expected given the size and position of the molars in the animal's mouth. The observed wear suggests that these were from sub-adult or adult dogs, yet the Kalavan-1 specimens are isolated finds, and wear stages as defined by Horard-Herbin (2000) could not be correlated with skeletal material in order to obtain age estimates. Moreover, as mentioned above, (C) Antiquity Publications Ltd, 2016 

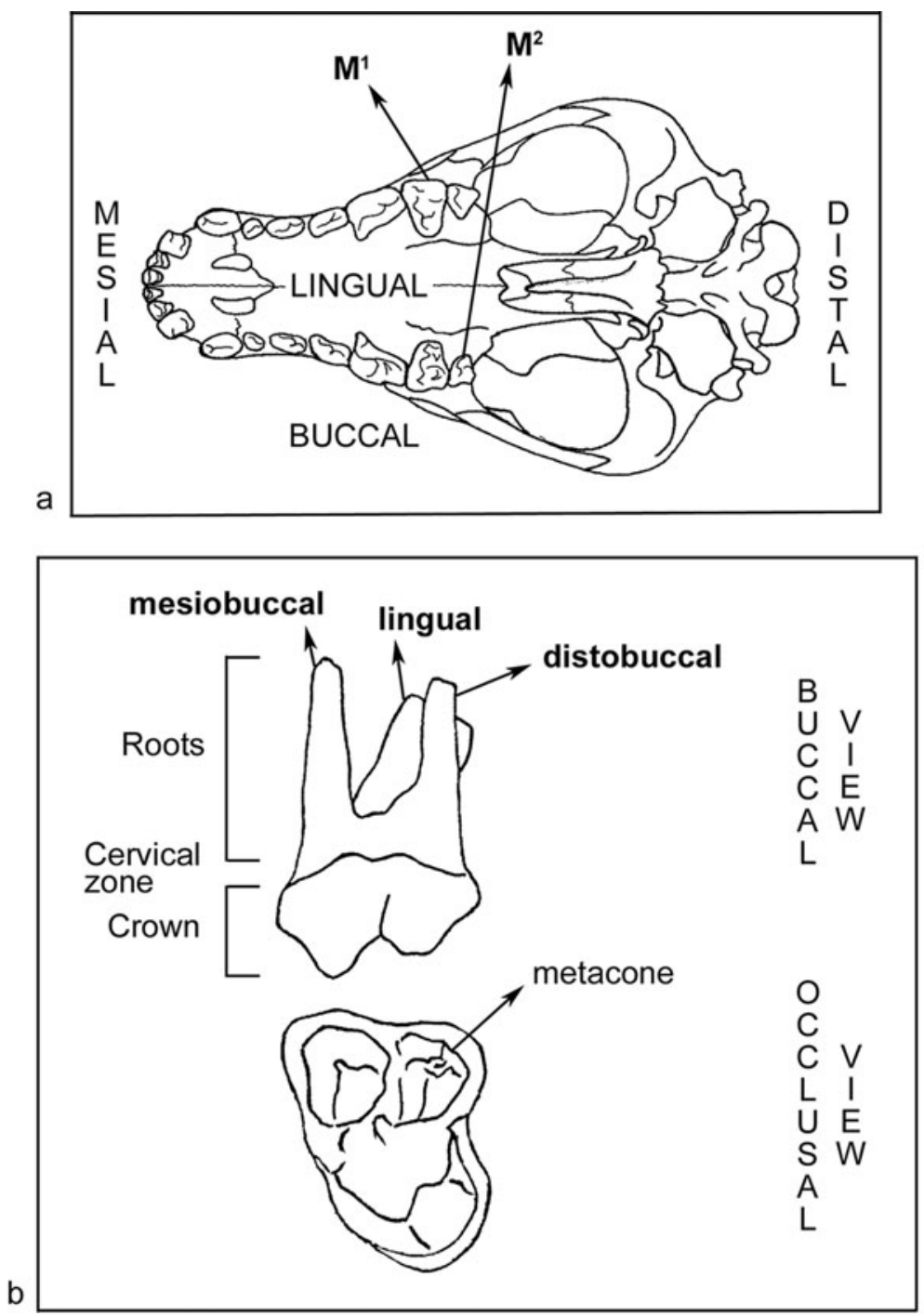

Figure 3. Canid dentition: a) upper jaw showing position of $M^{1}$ and $M^{2}$ (based on von den Driesch 1976: fig. 14c); b) schematic upper molar (based on Schmid 1972: fig. 19) with anatomical terms employed in the text.

regional data are too poor to permit evaluation of the tooth wear rate. Nor is it possible to know whether the two molars came from the same individual.

Both teeth are complete, but post-burial damage, consisting of cracking, pitting and flaking (Figures $4 \mathrm{a}-\mathrm{d} \& 5$ ), affects their entire surface. Encrustations, light abrasion and recent removals are also present. About $50 \%$ of the surface of $\mathrm{M}^{2}$ is affected; $\mathrm{M}^{1}$ has suffered more damage. Decay is more advanced on the human skeletal remains, which are brittle and easily pulverised. Temperature change and solifluction at Kalavan-1 have probably 

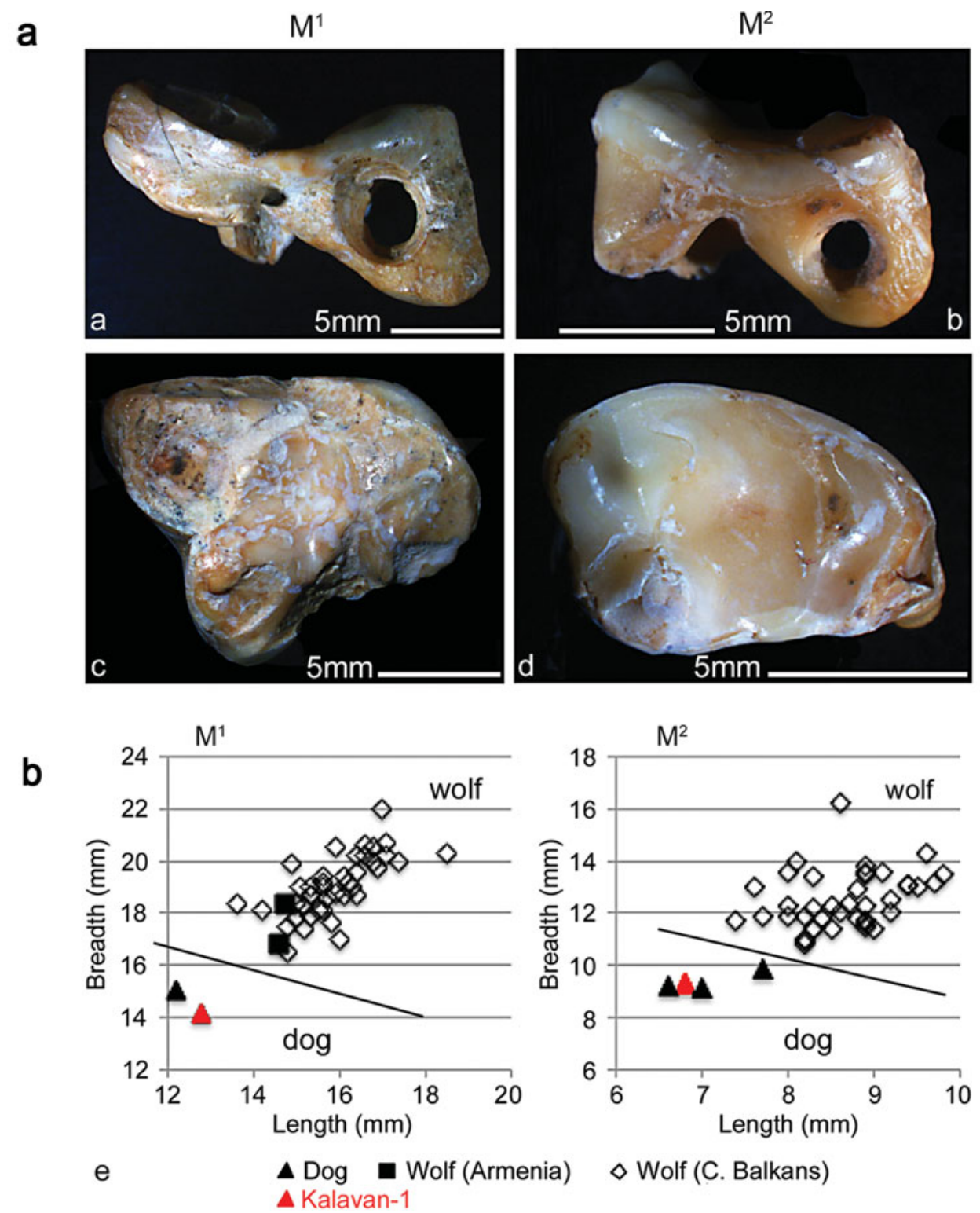

$\diamond$ Wolf (C. Balkans)

Figure 4. $a$ \& b) Mesial aspect of the Kalavan-1 dog molars; $c$ \& d) occlusal surfaces. The $M^{1}$ cusps are worn down at even height; the $M^{2}$ cusps are worn but clearly defined; the $M^{2}$ metacone is faceted; e) comparison of recent wolf $M^{1}$ and $M^{2}$ (Dimitrijević \& Vukovic 2015) and prehistoric specimens from Armenia. Summary of metrics in Table S1 in online supplementary material (see Table 3 for Kalavan-1; photographs by Rozalia Christidou).

aggravated bone corrosion. Soil composition was not studied, and the burial environment could not be examined as a potential agent of bone diagenesis.

The post-depositional effects on the teeth hindered observation of the manufacturing and use marks, but the overall pattern could be analysed. Manufacturing consisted of hole (C) Antiquity Publications Ltd, 2016 

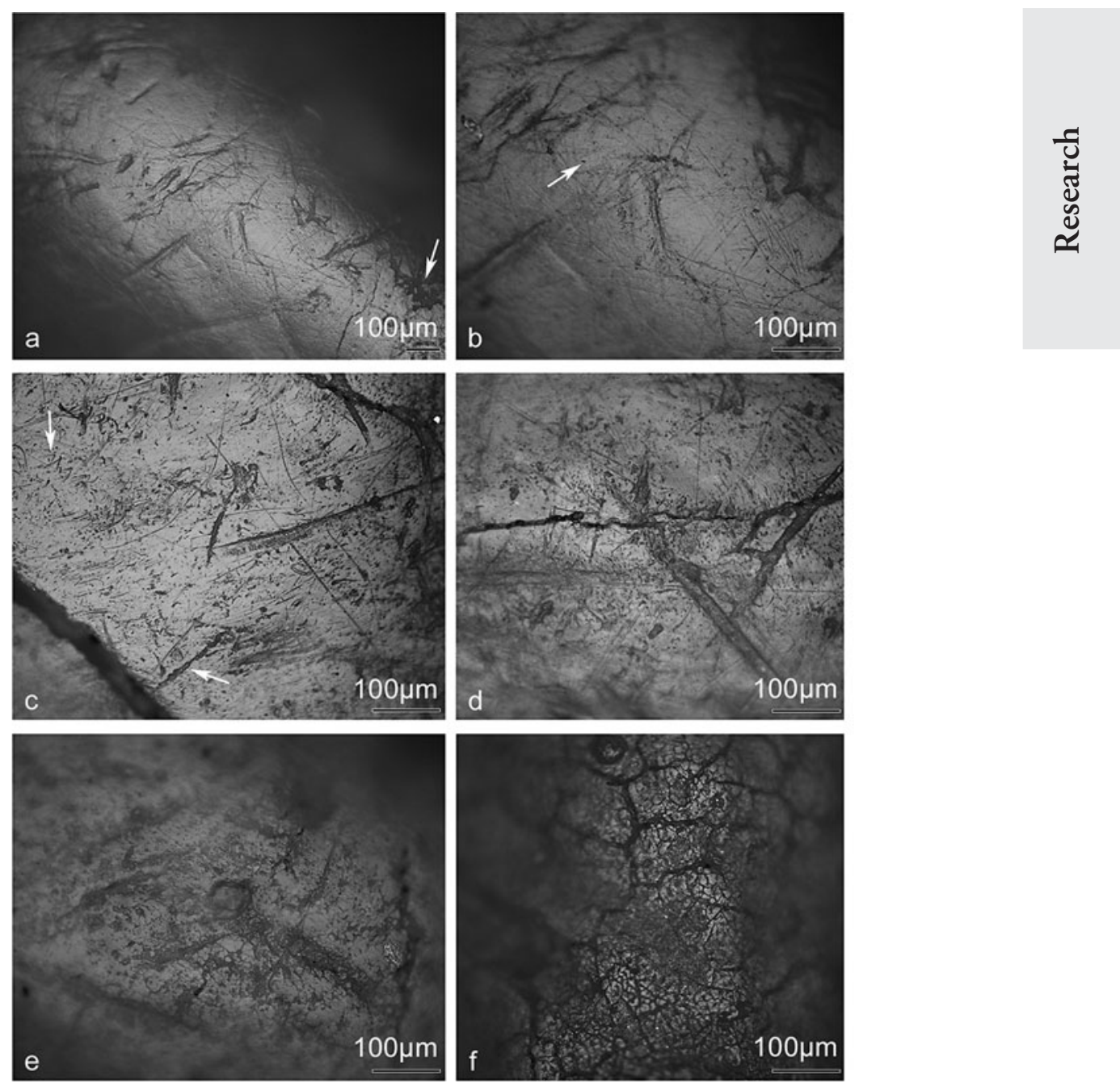

Figure 5. Post-burial modification of the Kalavan-1 dog molars: a \& b) $M^{1}$, crown, mesial view, pitted areas (indicated by arrows) appear unpolished; $c \& d$ d $M^{1}$, mesiobuccal root, the arrows show microscopic cracks (upper left) and abrasion (lower); e) $M^{1}$, lingual root, detail of cracked surface near the apex; f) $M^{2}$, mesiobuccal root, detail of cracked mesial surface (photographs by Rozalia Christidou).

shaping and root trimming. Both teeth were perforated by a circular hole cut through the lingual root in a mesiodistal direction, immediately below the cervical region. This root is shorter and more massive than the buccal roots (Figure 3b); it is also compressed mesiodistally, providing space for boring small holes (Table 3). The opening is slightly elongated in a coronal/buccal-apical/lingual direction on $\mathrm{M}^{1}$ and rounded on $\mathrm{M}^{2}$. The perforations were cut from opposite sides ('biconical'; Figures $6 \& 7$ ) using a revolving, tapered, lithic tool. On $\mathrm{M}^{2}$, the mesial cone is slightly deeper than the distal cone. The angles at which the perforations were made are slanted; cone profiles are lopsided, partly due

(C) Antiquity Publications Ltd, 2016 

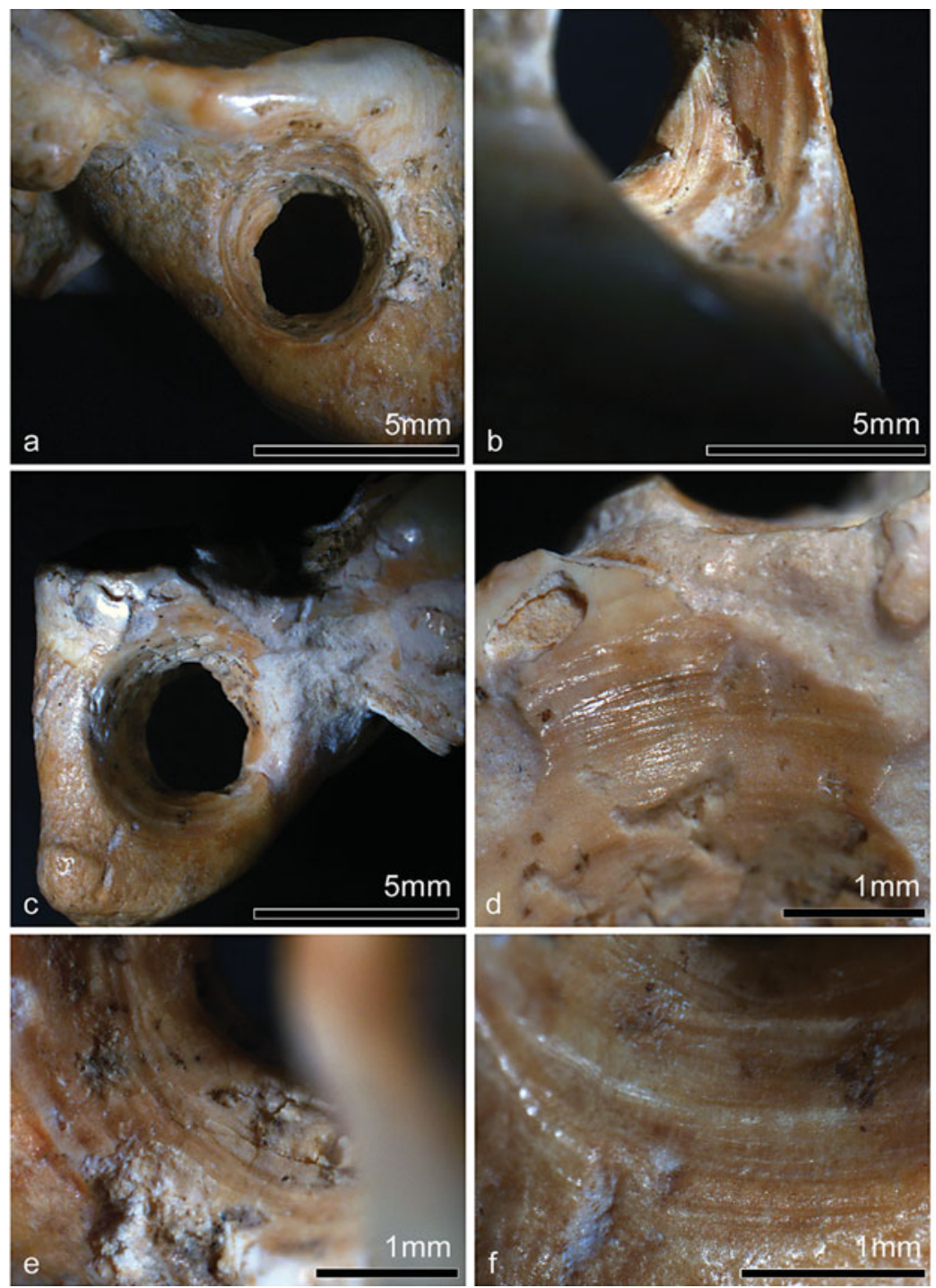

Figure 6. Kalavan-1 $\operatorname{dog} M^{1}:$ a) mesial cone, plan view; b) detail of the apical side of the cone; c) distal cone, plan view; d) detail of the occlusal side of the cone; $e$ \& $f$ ) apical side of the cone (photographs by Rozalia Christidou).

to the natural shape of the molars, which bulge above the roots. Overall, the outer edges of the holes appear sharp or flaring, indicating variations in the angles cut during the shaping of each one of the cones. The walls of the perforations (best preserved on $\mathrm{M}^{2}$ ) display groups of well-formed curving grooves separated by flat plateaus or ridges. Deviations from the intended course and intersections of linear marks also occur. These latter features and the profiles of the holes indicate changes in inclination and incomplete turns of the carving tool, and exclude uniform rotation by mechanical means or a hand drill (Stordeur 1977; Stordeur \& Pion 1993).

(C) Antiquity Publications Ltd, 2016 

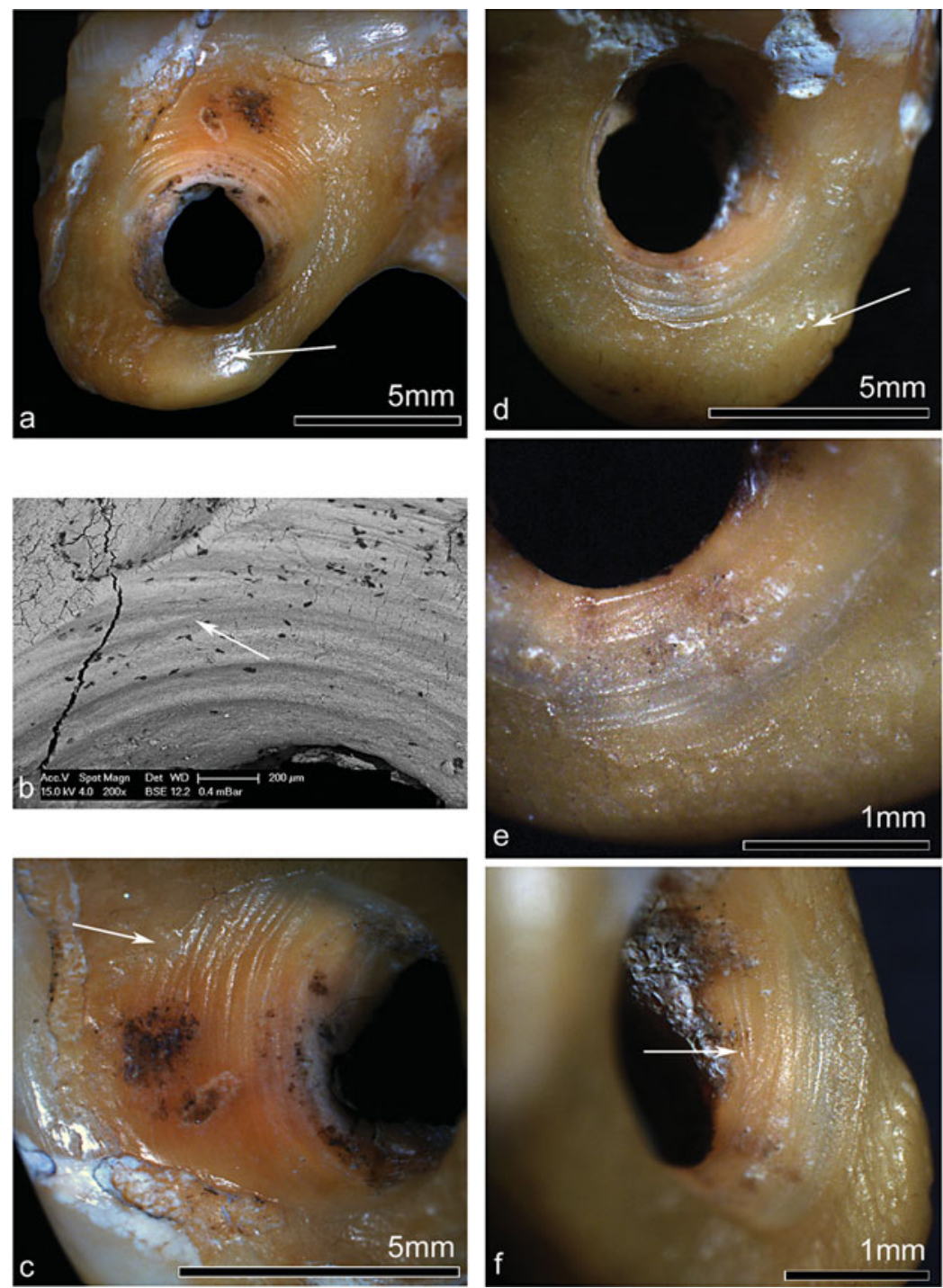

Figure 7. Kalavan-1 $\left.\operatorname{dog} M^{2}: a-c\right)$ mesial cone; $d-f$ ) distal cone; the arrows mark use polishing on (a) and (d) and intersecting striations on (b), (c) and ( $f$ ) (photographs by Rozalia Christidou).

The buccal roots were broken in order either to remove the teeth from the jaw or to reduce their length (Table 3; Figures $4 \mathrm{a}-\mathrm{b} \& 8 \mathrm{a}-\mathrm{b} \& \mathrm{~d}-\mathrm{e}$ ). Both buccal roots of $\mathrm{M}^{2}$ and the distobuccal root of $\mathrm{M}^{1}$ show $\mathrm{V}$-shaped fractures. Fracture type was not determined for the $\mathrm{M}^{1}$ mesiobuccal root, which was thoroughly worked after the breakage and almost completely removed. The broken end of the distobuccal root of $\mathrm{M}^{1}$ and the apex of the lingual roots (Figure 8b-c \& f) were flattened using grinding (cf. Figures $9 \& 10 \mathrm{e}$ ), creating small facets with variable inclinations. On the $\mathrm{M}^{2}$ mesiobuccal root, grinding was employed

(C) Antiquity Publications Ltd, 2016 

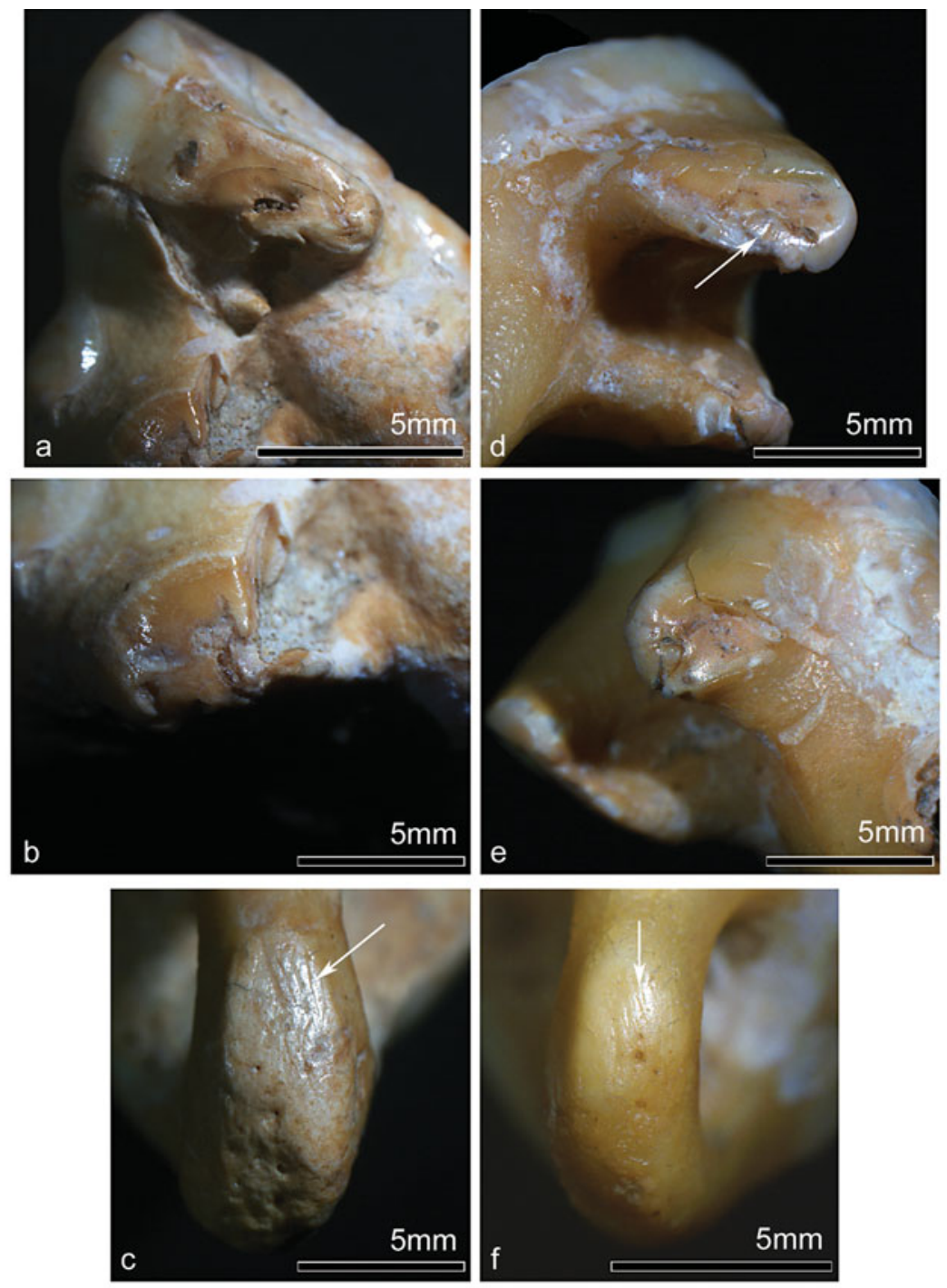

Figure 8. Apical view of the Kalavan-1 dog molars: $\left.a-c) M^{1} ; d-f\right) M^{2}$; mesiobuccal roots on the upper side of $(a)$ and $(d)$; lingual roots on $(c)$ and $(f)$; the arrows indicate shaping marks worn through use (photographs by Rozalia Christidou).

to smooth the high relief of the fracture surface (Figures $8 \mathrm{~d} \& 10 \mathrm{~b}$ ). The broken end of the $\mathrm{M}^{2}$ distobuccal root shows no further modification prior to use (Figure $8 \mathrm{e}$ ).

Use-wear on the teeth included polishing, rounding and smoothing, which was most developed on the root ends. The holes exhibit the highest degree of use-wear at the intersection of the cones, in the centre of the perforation. This wear is perceptible at low magnifications (e.g. Figure 7e), as are polishing and smoothing on the high natural relief between the apex of the lingual roots and the holes (Figure $7 \mathrm{a} \& \mathrm{~d}$ ) and on the perforation marks on the margin of the crown (Figure 7c). Under high magnification, three main wear (C) Antiquity Publications Ltd, 2016 

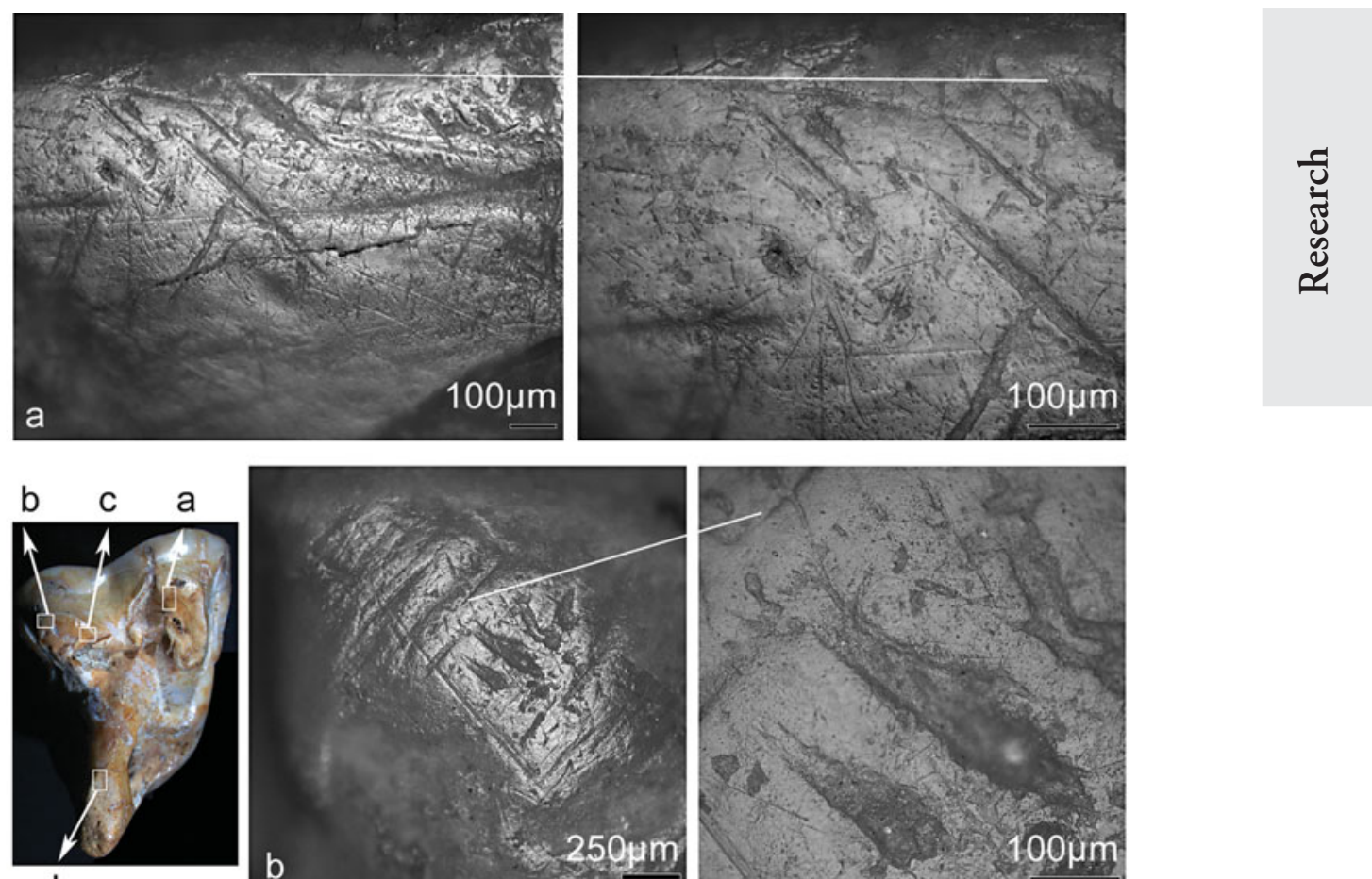

d
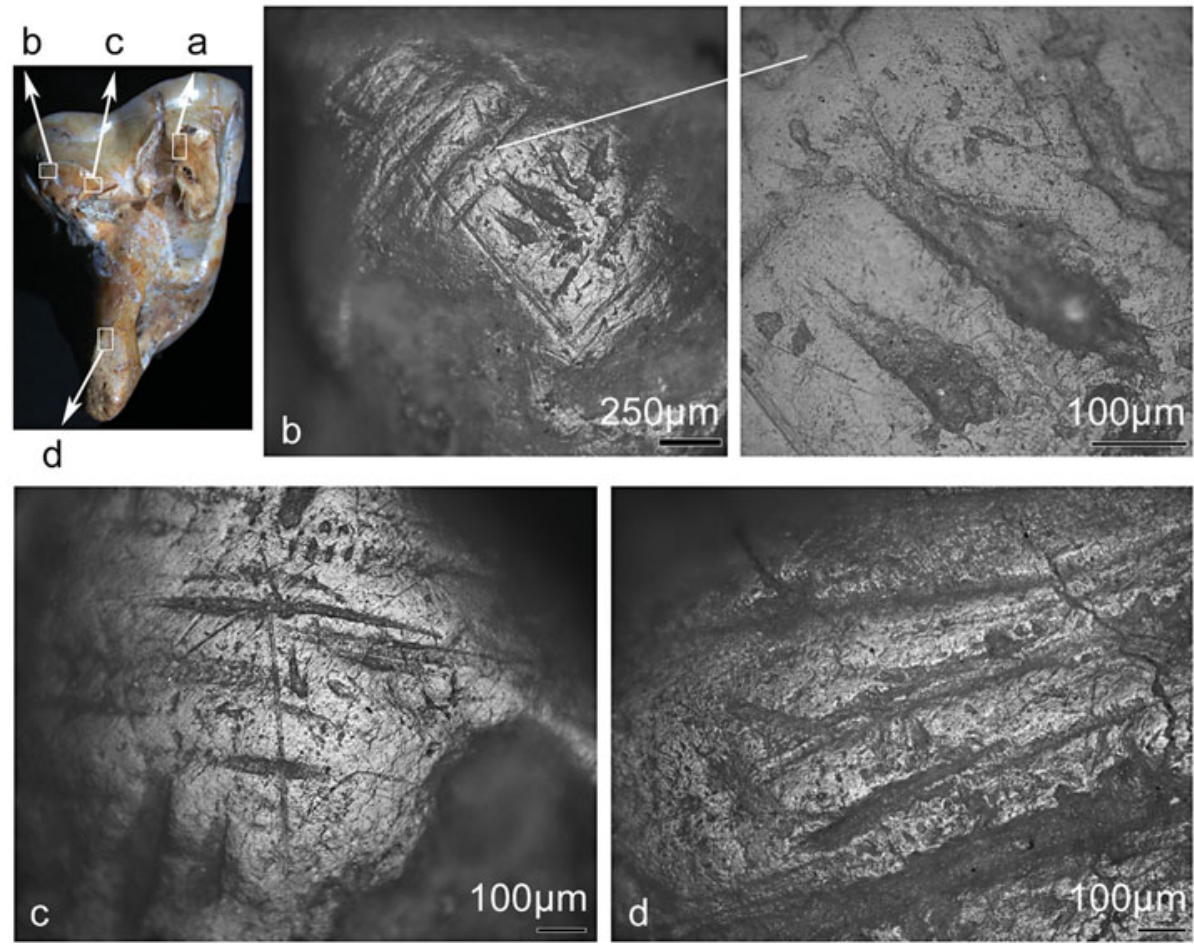

Figure 9. Kalavan-1 $\operatorname{dog} M^{1}$, root-end wear state: a) mesiobuccal; $b$ \& c) distobuccal; d) lingual facets; details for (a) and (b) at 200× (photographs by Rozalia Christidou).

patterns, corresponding to different degrees of use damage, were defined on the root ends (Table 4). Patterns B and C indicate heavy wear and are observed on the high relief (i.e. edges and convexities) of the root extremities. Wear fades away from these areas as shown by the presence of pattern $A$ on their margins (Figures 9d, 10b \& 11a). The polishing is somewhat developed farther away, towards the holes and in low-relief areas (Figure 11b). Greater wear on the margin of the crown, as described above, is a result of these raised areas being more exposed to friction. 

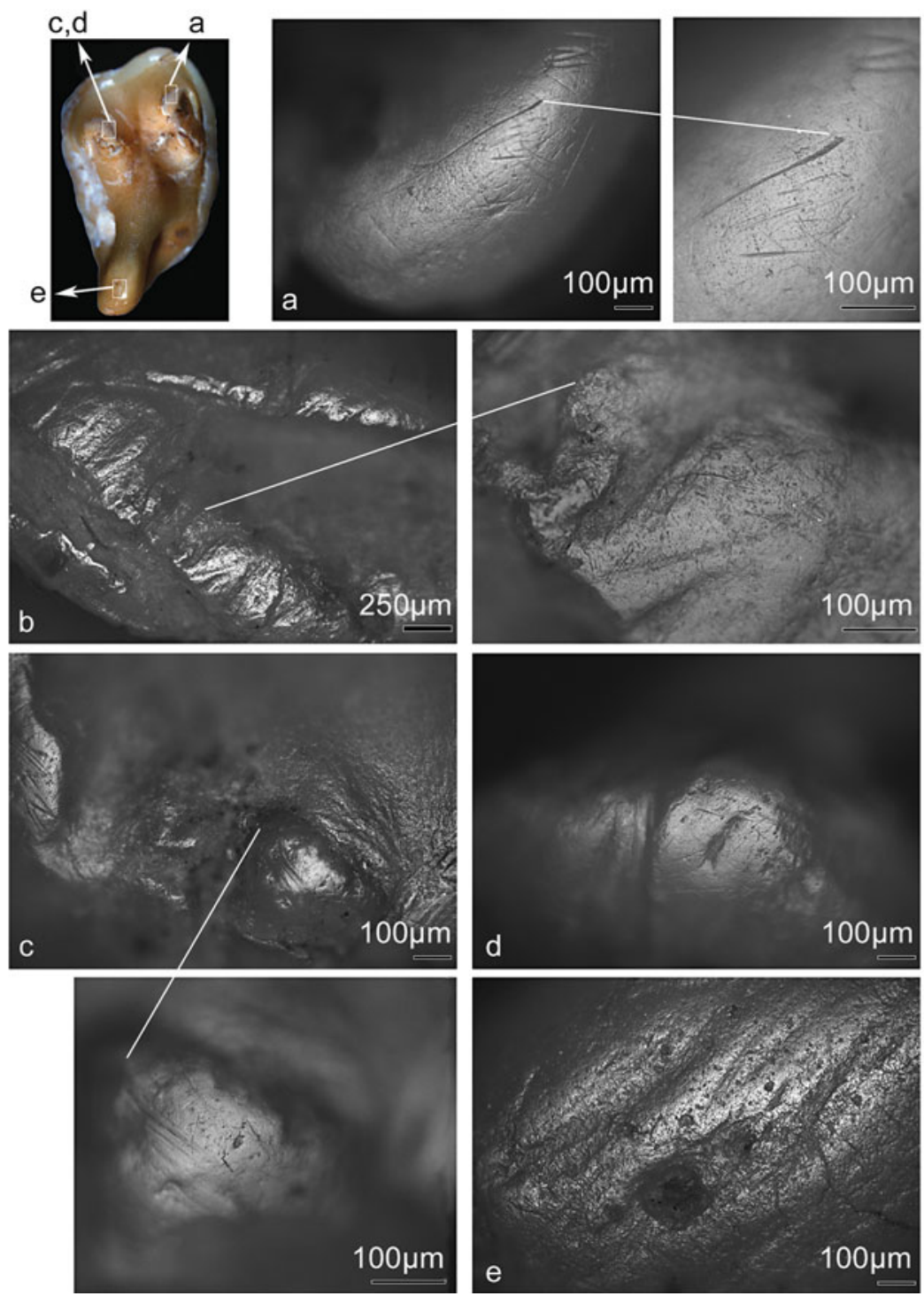

Figure 10. Kalavan-1 $\operatorname{dog} M^{2}$, root-end wear state: a) mesiobuccal root, extremity; b) mesiobuccal root, ground surface; $c$ \& d) distobuccal root, extremity, distal and mesial views; e) lingual facet; details for (a), (b) and (c) at 200 $\times$ (photographs by Rozalia Christidou).

The outer parts of the holes show use-wear on the highest points of the original surface relief (Figure 11c-e). Towards the inner part of the cones, the grooved topography is preserved, but use-wear becomes stronger, as indicated by worn-down valleys and homogeneous, smoothed and polished plateaus; the polishing is crossed by closely packed fine striations that are perpendicular or oblique to the manufactured grooves. This wear appears mainly on and near the apical region of the holes and is connected to the smoothing (C) Antiquity Publications Ltd, 2016 
Table 4. Root-end wear state defined at $200 \times$ magnification. Topography is also observed at $100 \times$ magnification. Use striations on $B$ and $C$ surfaces have no preferred orientation. The amount of use pits is difficult to evaluate due to post-depositional damage.

Shaped topography (structured by oriented wide rough-bottomed

Figures $9 \mathrm{~d} \& 10 \mathrm{~b}$

striations) preserved. Use-wear (consisting of polishing, rounding and incomplete smoothing of the raised areas of the topography) extending into low-relief areas (i.e. valleys). (Most of the) plateaus homogeneous with narrow dark or polished abrasion features. Amount of wear in valleys dependent on valley depth.

B Similar to A, with homogeneous, smoothed extensive plateaus and shallow, more or less worn and polished valleys.

C Uniformly smoothed and polished surface with random, more or less worn and polished striations. No recognisable, or few deep, valleys of the original topography preserved.

Figures $9 \mathrm{a}-\mathrm{c} \&$

$10 \mathrm{c} \& \mathrm{e}$

Figure $10 \mathrm{a} \& \mathrm{~d}$

of their internal edge (Figure 11f). The limits of these modifications are either undetermined because of accidental damage, or ill-defined because the wear faded out.

Artificial and post-burial wear and tear indicates similar processes of manufacturing, use and post-depositional damage. The shaping process shows minor variations mostly related to the treatment of the roots. The nature and amount of use-wear on the apical side of the molars and on the protruding rim of the tooth crown suggest loose but prolonged contact with soft animal tissue, as well as handling (e.g. d'Errico 1993; Stordeur \& Christidou 2008). The type and distribution of the wear within the perforations and on their margins towards the apex of the lingual root show that a thread of plant fibres passed through the hole, and that the molars were suspended. The location of the perforations on the lingual roots indicates that the crowns would be the most visible part of the teeth, which were probably worn as pendants.

\section{Discussion}

The choice of upper dog molars and the shaping and use of the objects made from these teeth indicate an orderly pattern. Both specimens were worked using the same method in order to be used in the same way, probably as part of the ornamental cluster that included the stone beads. Figure 12 reveals the lack of consistency and symmetry; shapes, sizes and colours vary. No technological study of the stone beads has been conducted, but it is probable that texture, and therefore touch and reflectivity, also varied and perhaps influenced the perception and the meaning of the colours (e.g. Pastoureau \& Simonnet 2010: 35). The raw materials appear distinctive: the white crowns of the teeth, which show no deliberate modification, contrast with the red and blue shaped stone pieces. The manufacturing technique of the perforated molars indicates simple preparation for displaying the crown; there is no evidence of skilful shaping or finishing, suggesting that any individuality or style was intrinsic and not created by the manufacturing process. Moreover, tooth eruption and occlusal wear imply that the $\operatorname{dog}(s)$ from which the molars were derived had lived long enough to develop ties with humans, possibly with the wearer. Such links would explain the choice of molars and personalise the ornament. On the other hand, recent discoveries within the territory of the 

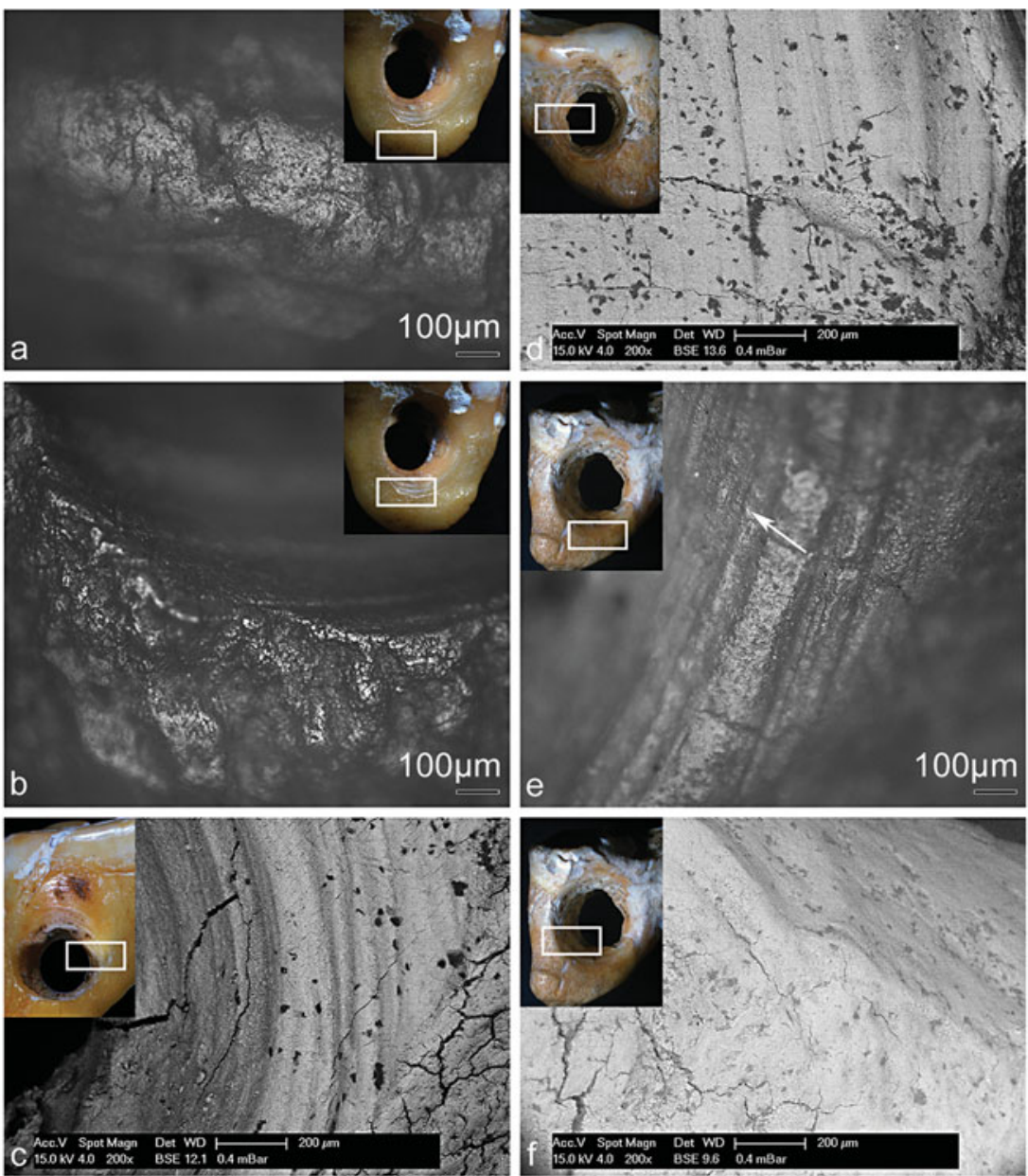

Figure 11. Holes: a) $M^{2}$, distal view, homogenised margin of the apex (cf. Figure $7 a$ \& d); b) $M^{2}$, distal view, natural topography unmodified, uneven, superficial polishing; c) $M^{2}$, mesial view, shaped topography unmodified, light use-wear; d) $M^{1}$, mesial view, shaped upper relief, rounding; e) $M^{1}$, distal view, shaped upper relief, use striations (indicated by the arrow) and polishing; f) $M^{1}$, internal edge, smoothing (photographs $a, b$ \& e by Rozalia Christidou; $c$, \& $f$ by Hala Alarashi).

Republic of Armenia hint that dogs and wolves played a symbolic role in the burial and cultic practices of the Kura-Araxes populations. These findings include dog teeth collected in the dromos of mound N1 of the Jrvezh necropolis near Yerevan (Tumanyan 1993) and a votive deposit of seven wolf skulls from the cult building of Mets Sepasar, north-west Armenia (Yeganyan 2011). These are dated to the early and late Kura-Araxes, respectively.

The cemetery site, the grave type and the adult grave goods of Kalavan-1 conform to the Kura-Araxes burial customs and artefact repertoire, indicating cultural unity. The small cluster of graves suggests use by a residential or kin group, representative of the social structure of the period. The perforated dog molars represent, in many respects, an unusual piece of work, perhaps an adaptation or new element in the funerary symbolism. Such changes (C) Antiquity Publications Ltd, 2016 
can involve materials, objects and styles from various sources that were used as symbols. The production and use of ornaments from the dog molars may have borrowed from the

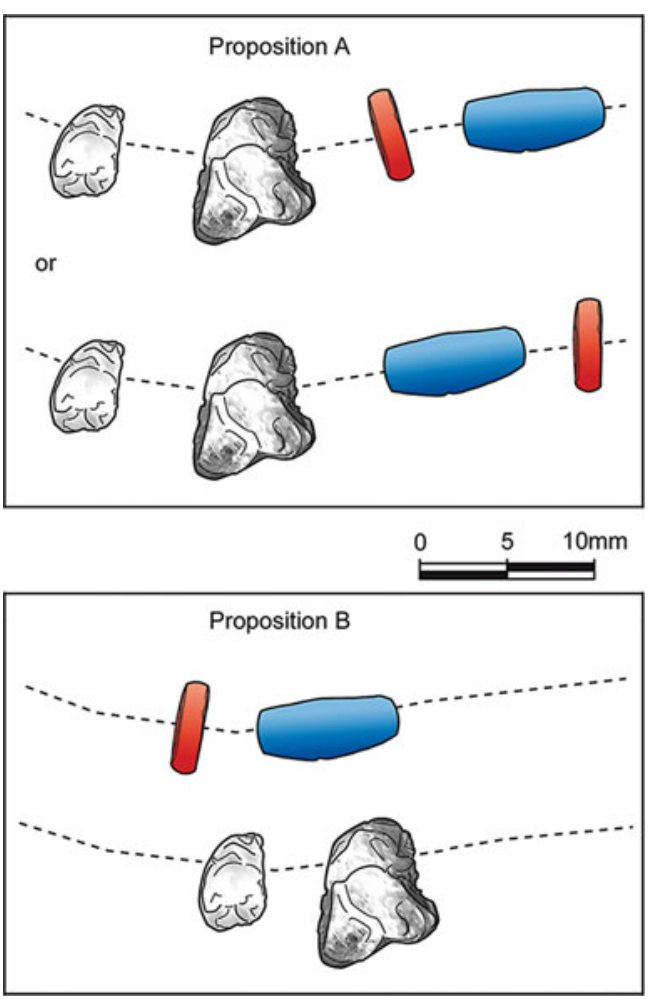

Figure 12. Two possible reconstructions of the neckornament incorporating the dog molars and the carnelian (in red) and blue stone (in blue) beads, based on the excavation data (drawn by Hala Alarashi).
Kura-Araxes cult or other burial practices, pointing to a desire to modify symbolism. The ornaments could embody kin or cultural affiliation, or even age differentiation, as the adult burials yielded other kinds of burial goods. Nevertheless, the distribution of the Kura-Araxes funerary objects does not seem to have been age-related. Either way, the seemingly eclectic taste of the neckornament could express a desire to connect with wider trends within the Kura-Araxes sphere, as well as communicate a spirit of change.

Technological analysis is often conducted in order to discover the perceptions that structure the choice and use of raw materials. In the present study, technological data supplement contextual evidence and prompt examination of the means by which, and the extent to which, individual or group agency contributed to the evolution of the Kura-Araxes phenomenon. Local use of the ornament type examined probably reflects a context-bound process of appropriation and classification, but it cannot predict the way (e.g. observation or oral communication) in which knowledge of the type was acquired. Prediction would require monitoring diachronic and cross-cultural uses and manufacturing modes of the ornament, and bridging gaps created by research organised on a regional basis.

\section{Acknowledgements}

Permits and facilities for the excavation and study of material from Kalavan-1 were offered by Pavel Avetisyan and Boris Gasparyan (IAE-NAS RA). The French Ministry of Foreign Affairs ('Mission Caucase') and the Armenian Branch of the Gfoeller Fund of the America Corporation provided financial support. We acknowledge: Alexandra Legrand and Régis Vallet for providing access to SIMO-MAE (Nanterre) for optical analysis of the molars; and Suzanne Jacomet for help with SEM analysis at CEMEF (Sophia Antipolis). Danielle Stordeur was the first to examine the ornaments. Ruben Badalyan answered questions about absolute dates from Kura-Araxes sites. Sevil Gülçur, Panagiotis Karkanas, Alexandra Legrand and Dimitra Malamidou made comments on the draft of the document. We also thank: Laurence Astruc for consistent support at Nanterre; Anne Bridault for advice and comparisons with osteological reference material; Jwana Chahoud, Alice Choyke, Lionel Gourichon, Heidi Luik and Gaëlle Le Dosseur for answers to questions about dog molars; Cyril Montoya for a helpful report on the stratigraphy of Kalavan-1; and Hara Procopiou and Giulio Palumbi for bibliographical aid. Thanks, too, 
go to Frédéric Abbès for knapping obsidian used to verify perforation marks by experiment. Lastly, we want to express our great appreciation for the recommendations of Philip Kohl and the two anonymous reviewers that helped improve the paper.

\section{Supplementary material}

To view online supplementary material for this article, please visit http://dx.doi.org/ 10.15184/aqy.2016.132.

\section{References}

BăLĂŞESCU, A., E. Vila, V. RadU, R. Badalyan \& C. Chataigner. 2010. Production animale et économie de subsistance au Néolithique dans la plaine de l'Ararat (Arménie). Annales d'Université 'Valahia' Târgoviște, Section d'Archéologie et d'Histoire XII.1: 25-38.

Barge-Mahieu, H. \& Y. Taborin. 1991. Fiche générale des dents percées, in H. Camps-Fabrer (ed.) Fiches typologiques de l'industrie osseuse préhistorique. Cahier IV. Objets de parure: 29-36. Aix-en-Provence: Université de Provence.

Bernabò Brea, M., P. Mazzieri \& R. Micheli. 2010. People, dogs and wild game: evidence of human-animal relations from Middle Neolithic burials and personal ornaments in northern Italy. Documenta Praehistorica 37: 125-45. http://dx.doi.org/10.4312/dp.37.11

Berthon, R., A. Decaix, Z.E. Kovaćs, W. van NeEr, M. Tengberg, G. Willcox \& T. Cucchi. 2013. A bioarchaeological investigation of three late Chalcolithic pits at Ovçular Tepesi (Nakhchivan, Azerbaijan). Journal of Environmental Archaeology 18: 191-200. http: //dx.doi.org/10.1179/1749631413Y.0000000005

BRUZEK, J. 2002. A method for visual determination of sex, using the human hip bone. American Journal of Physical Anthropology 117: 157-68. http://dx.doi.org/10.1002/ajpa.10012

Chataigner, C. \& G. Palumbi (ed.). 2014. The Kura-Araxes culture from the Caucasus to Iran, Anatolia and the Levant: between unity and diversity. Paléorient 40. Paris: CNRS.

Chataigner, C., B. Gasparyan, C.A. Montoya, M. Arimura, V. Melikyan, J. Liagre, A. Petrosyan, R. Ghukasyan, D. Colonge, C. Fourloubey, D. Arakelyan, L. Astruc, S. Nahapetyan, R. Hovsepyan, A. Balasescu, C. Tomé \& V. Radu. 2012. From the Late Upper Palaeolithic to the Neolithic in north-western Armenia: preliminary results, in P. Avetisyan \& A. Bobokhyan (ed.) Archaeology of Armenia in regional context. Proceedings of the International Conference dedicated to the $50^{\text {th }}$ anniversary of the Institute of Archaeology and Ethnography, held on September 15-17, 2009, in Yerevan: 37-43, 157-62. Yerevan: Gitutyun.
CHOrke, A.M. 2010. The bone is the beast: animal amulets and ornaments in power and magic, in D.V. Campana, P. Crabtree, S.D. deFrance, J. Lev-Tov \& A.M. Choyke (ed.) Anthropological approaches to zooarchaeology: colonialism, complexity and animal transformations: 197-209. Oxford: Oxbow.

Choyke, A.M., M. Vretemark \& S. STen. 2004. Levels of social identity expressed in the refuse and worked bone from Middle Bronze Age Százhalombatta-Földvár, Vatya culture, Hungary, in S. Jones O’Day, W. van Neer \& A. Ervynck (ed.) Behaviour behind bones. The zooarchaeology of ritual, religion, status and identity. Proceedings of the $9^{\text {th }}$ Conference of the International Council of Archaeozoology, Durham, August 2002: 177-89. Oxford: Oxbow.

Copet-Rougier, E. 1988. Le jeu de l'entre-deux. Le chien chez les Mkako (Est-Cameroun). L'Homme 28: 108-21. http://dx.doi.org/10.3406/hom.1988.369047

D’ERrICO, F. 1993. Identification des traces de manipulation, suspension, polissage sur l'art mobilier en os, bois de cervidé, ivoire, in P.C. Anderson, S. Beyries, M. Otte \& H. Plisson (ed.) Traces et fonctions: les gestes retrouvés. Actes $d u$ Colloque International de Liège, 8-9-10 décembre 1990 (ERAUL 50): 177-88. Liège: CNRS.

Dimitrijević, V. \& S. VuKović. 2015. Was the dog locally domesticated in the Danube Gorges? Morphometric study of dog cranial remains from four Mesolithic-Early Neolithic archaeological sites by comparison with contemporary wolves. International Journal of Osteoarchaeology 25: 1-30. http://dx.doi.org/10.1002/oa.2260

DriesCH, A. VON DEN. 1976. A guide to the measurement of animal bones from archaeological sites (Peabody Museum Bulletin 1). Cambridge (MA): Peabody Museum of Archaeology and Ethnology, Harvard University.

DudAY, H. 2009. The archaeology of the dead. Lectures in archaeothanatology (translated by A.M. Cipriani \& J. Pearce). Oxford: Oxbow. 


\section{Unusual personal ornaments made from dog molars}

Frangipane, M., G.M. Di Nocera, A. Hauptmann, P. Morbidelli, A. Palmieri, L. Sadori, M. SchulTz \& T. SCHMidT-SCHUlTz. 2001. New symbols of a new power in a 'royal' tomb from 3000 BC Arslantepe, Malatya (Turkey). Paléorient 27: 105-39.

http://dx.doi.org/10.3406/paleo.2001.4733

Grosman, L. 2003. Preserving cultural traditions in a period of instability: the late Natufian of the hilly Mediterranean zone. Current Anthropology 44: 571-80. http://dx.doi.org/10.1086/377650

Hamilakis, Y. 2002. Too many chiefs? Factional competition in Neopalatial Crete, in J. Driessen, I. Schoep \& R. Lafinneur (ed.) Monuments of Minos: rethinking the Minoan palaces. Proceedings of the International Workshop 'Crete of the hundred palaces?' held at the Université catholique de Louvain, Louvain-la-Neuve, 14-15 décembre 2001 (Aegaeum 23): 179-99. Liège: Université de Liège \& University of Texas at Austin.

Horard-Herbin, M.-P. 2000. Dog management and use in the Late Iron Age: the evidence from the Gallic site of Levroux (France), in S.J. Crockford (ed.) Dogs through time: an archaeological perspective. Proceedings of the $1^{\text {st }}$ ICAZ Symposium on the History of the Domestic Dog, Eighth Congress of the International Council for Archaeozoology (ICAZ98), August 23-29, 1998 Victoria, B.C., Canada (British Archaeological Reports international series 889): 115-21. Oxford: Archaeopress.

KOHL, P.L. 2009. Origins, homelands and migrations: situating the Kura-Araxes Early Transcaucasian 'culture' within the history of Bronze Age Eurasia. Tel Aviv 36: 241-65.

LEgrand, A. \& I. SidÉRA. 2007. Methods, means, and results when studying European bone industries, in C. Gates St-Pierre \& R.B. Walker (ed.) Current methods and interpretations in worked bone studies (British Archaeological Reports international series 1622): 67-79. Oxford: Archaeopress.

LOSEY, R., V.I. BAZALIISKI, S. GARVIE-LOK, M. Germonpré, J.A. LeOnard, A.L. Allen, M.A. Katzenberg \& M.V. Sablin. 2011. Canids as persons: early Neolithic dog and wolf burials, Cis-Baikal, Siberia. Journal of Anthropological Archaeology 30: 174-89. http://dx.doi.org/10.1016/j.jaa.2011.01.001

LÓUGAS, L. 2006. Animals as subsistence and bones as raw material for settlers of prehistoric Zvejnieki, in L. Larsson \& I. Zagorska (ed.) Back to the origin. New research in the Mesolithic-Neolithic Zvejnieki cemetery and environment, northern Latvia (Acta Archaeologica Lundensia series 52): 75-89. Lund: Almqvist \& Wiksell International.
MannermaA, K., I. ZagorskA, H. JUNGNer \& G. ZARINA. 2007. New radiocarbon dates of human and bird bones from Zvejnieki Stone Age burial ground in northern Latvia. Before Farming 2007(1): 1-12. http://dx.doi.org/10.3828/bfarm.2007.1.3

Mirzoyan, L. \& N. Manaseryan. 2008.

Archaeozoological investigation of the site of Shirakavan, $3^{\text {rd }}-1^{\text {st }}$ millennia BC, Armenia, in E. Vila, L. Gourichon, A. Choyke \& H. Buitenhuis (ed.) Archaeozoology of the Near East VIII.

Proceedings of the Eighth International Symposium on the Archaeozoology of Southwestern Asia and Adjacent Areas, Lyon, June 28 $8^{\text {th }}$-July $1^{\text {st }}$, 2006, Tome II (Travaux de la Maison de l'Orient et de la Méditerranée 49): 521-31. Lyon: Maison de l'Orient et de la Méditerranée.

Montoya, C., A. Balasescu, S. Joannin, V. Ollivier, J. Liagre, S. NaHAPETyan, R. GHUKASYAN, D. Colonge, B. Gasparyan \& C. Chataigner. 2013. The Upper Palaeolithic site of Kalavan 1 (Armenia): an Epigravettian settlement in the Lesser Caucasus. Journal of Human Evolution 65: 621-40. http://dx.doi.org/10.1016/j.jhevol.2013.07.011

Moorrees, C.F.A., E.A. FAnNing \& E.E. Hunt. 1963. Age variation of formation stages for ten permanent teeth. Journal of Dental Research 42: 1490-502. http: //dx.doi.org/10.1177/00220345630420062701

Morey, D.F. 2010. Dogs: domestication and the development of a social bond. Cambridge: Cambridge University Press. http://dx.doi.org/10.1017/CBO9780511778360

Pastoureau, M. \& D. Simonnet. 2010. Le petit livre des couleurs. Paris: Seuil.

Piro, J. 2008. Pastoral economies in Early Transcaucasian communities from the mid $-4^{\text {th }}$ to $3^{\text {rd }}$ millennium BC, in E. Vila, L. Gourichon, A. Choyke \& H. Buitenhuis (ed.) Archaeozoology of the Near East VIII. Proceedings of the Eighth International Symposium on the Archaeozoology of Southwestern Asia and Adjacent Areas, Lyon, June $28^{\text {th }}$-July $1^{\text {st }}$, 2006, Tome II (Travaux de la Maison de l'Orient et de la Méditerranée 49): 451-63. Lyon: Maison de l'Orient et de la Méditerranée.

Poulmarc'H, M. (with L. Pecqueur \& B. Jalilov). 2014. An overview of Kura-Araxes funerary practices in the southern Caucasus, in C. Chataigner \& G. Palumbi (ed.) The Kura-Araxes culture from the Caucasus to Iran, Anatolia and the Levant: between unity and diversity (special issue). Paléorient 40: 233-48. Paris: CNRS.

Poulmarc'H, M. \& F. LE MORT. 2016. Diversification of the funerary practices in the southern Caucasus from the Neolithic to the Chalcolithic. Quaternary International 395: 184-93.

http://dx.doi.org/10.1016/j.quaint.2015.04.040 
SCHMID, E. 1972. Atlas of animal bones: for prehistorians, archaeologists and Quaternary geologists. Amsterdam: Elsevier.

SCHMITT, A. 2005. Une nouvelle méthode pour estimer l'âge au décès des adultes à partir de la surface sacro-pelvienne iliaque. Bulletins et Mémoires de la Société d'Anthropologie de Paris (N.S.) 17: 89-101.

SEWELL, W.H., JR. 1999. The concept(s) of culture, in V.E. Bonnell \& L. Hunt (ed.) Beyond the cultural turn: new directions in the study of society and culture: 35-61. Berkeley \& Los Angeles: University of California Press.

SMith, A.T. 2005. Prometheus unbound: southern Caucasia in prehistory. Journal of World Prehistory 19: 229-79. http://dx.doi.org/10.1007/s10963-006-9005-9

- 2012. The Caucasus and the Near East, in D.T. Potts (ed.) A companion to the archaeology of the ancient Near East: 668-86. London: Wiley-Blackwell. http://dx.doi.org/10.1002/9781444360790

STORDEUR, D. 1977. La fabrication des aiguilles à chas. Observation et experimentation, in H. Camps-Fabrer (ed.) Méthodologie appliquée à l'industrie de l'os préhistorique. Deuxième colloque international sur l'industrie de l'os dans la préhistoire, Abbaye de Sénanque (Vaucluse) 9-12 juin 1976: 251-56. Paris: CNRS.

Stordeur, D. \& R. Christidou. 2008. L'industrie osseuse de Mureybet: étude morpho-technique et fonctionnelle, in J.J. Ibáñez (ed.) Le site néolithique de Tell Mureybet (Syrie du Nord). En hommage à Jacques Cauvin (British Archaeological Reports international series 1843): 439-537. Oxford: Archaeopress.
Stordeur, D. \& G. PiON. 1993. La plaquette perforee en os de la Fru à Saint-Christophe (Savoie): premier temoignage d'un forage alternatif. Gallia préhistoire 35: 293-304.

TuMANYAN, G.S. 1993. Jrvezhi vaghbronzedaryan N1 dambanabluri peghumnery, in G.A. Tiratsyan, A.A. Kalantaryan \& G.E. Areshyan (ed.) Hnagitakan ashkhatanknery Hayastani norakaruytsnerum I (1986-1987 tt. peghumneri ardyunknery). G.A. Tiratsyani hishatakin: 7-14. Yerevan: National Academy of Sciences of Armenia.

VANHAEREN, M. \& F. D'ERrico. 2006. Aurignacian ethno-linguistic geography of Europe revealed by personal ornaments. Journal of Archaeological Science 33: 1105-28. http://dx.doi.org/10.1016/j.jas.2005.11.017

Wilkinson, K.N., B. Gasparyan, R. Pinhasi, P. Avetisyan, R. Hovsepyan, D. Zardaryan, G.E. Areshian, G. Bar-Oz \& A. Smith. 2012. Areni-1 Cave, Armenia: a Chalcolithic-Early Bronze Age settlement and ritual site in the southern Caucasus. Journal of Field Archaeology 37: 20-33. http: //dx.doi.org/10.1179/0093469011Z.0000000002

YEGANYAN, L. 2011. Zhertvoprinoshenie volkov v rannebronzovom Mets Sepasare, in G. Gambashidze (ed.) Mezhdunarodnyaya nauchnaya konferentsiya 'Arkheologiya, Etnologiya i Fol'kloristika Kavkaza'. Sbornik kratkikh soderzhaniy dokladov: 119. Tbilisi: Meridiani.

Received: 24 July 2014; Accepted: 9 October 2014; Revised: 11 May 2015

(C) Antiquity Publications Ltd, 2016 
Copyright of Antiquity is the property of Cambridge University Press and its content may not be copied or emailed to multiple sites or posted to a listserv without the copyright holder's express written permission. However, users may print, download, or email articles for individual use. 